\title{
Incidence of Breast, Prostate, Testicular and Thyroid Cancer in Italian Contaminated Sites with Presence of Substances with Endocrine Disrupting Properties
}

\author{
Marta Benedetti *, Amerigo Zona, Eleonora Beccaloni, Mario Carere, Pietro Comba \\ Department of Environment and Health, Istituto Superiore di Sanità, Viale Regina Elena 299, Rome, 00161, \\ Italy; amerigo.zona@iss.it;eleonora.beccaloni @iss.it; mario.carere@iss.it;pietro.comba@iss.it \\ * Correspondence: marta.benedetti@iss.it Tel.: +39-06-4990-3018
}

\begin{abstract}
The aim of the present study was to investigate the incidence of breast (females), prostate, testicular and thyroid cancer in the Italian National Priority Contaminated Sites (NPCSs), served by cancer registries, where the presence of endocrine disruptors (EDs), reported to be linked to these tumors, was documented. Evidence of carcinogenicity of EDs present in NPCs was assessed based on evaluation by international scientific institutions/committees. Standardized Incidence Ratios (SIRs) were computed for each NPCS and cancer site with reference to the time window 1996-2005. Excess incidence of one or more cancer site at study was found in twelve out of fourteen NPCSs. Significantly increased SIRs were found for breast cancer in eight NPCSs, for prostate cancer in six, for thyroid cancer (both gender) in four and for testicular cancer in two. Non significantly increased SIRs were found in five NPCSs for testicular cancer and in two for thyroid cancer (males). Even if increased incidence of one or more cancer sites at study were found in several NPCSs, the ecological study design and the multifactorial etiology of the considered tumors do not allow reaching conclusions in terms of causal links with environmental contamination. In light of the observation of some excesses in SIRs, continuing epidemiological surveillance is warranted.
\end{abstract}

Keywords: cancer; incidence; endocrine disruptors; environmental exposure

\section{Introduction}

Over the past decade, in industrialized countries served by cancer registries, an increased incidence of breast, prostate, testicular and thyroid cancer has been observed. The increase in incidence of endocrine-related cancers in humans cannot be explained solely in terms of genetics, better diagnosis or life style. Currently, it is believed that the increase may be partially related to exposure to environmental chemicals, some of which with endocrine disrupting properties [1].

An endocrine disruptor (ED) is commonly defined as an exogenous substance or mixture that interfere with the production, release, transport, metabolism, binding, action, or elimination of the natural hormones, and consequently causes adverse health effects in an intact organism, or its progeny, or (sub)population [1-2]. Similar to hormones, EDs can act at low dose, may have non-monotonic dose responses, will have tissue specific and time effects, will show different effects and dose responses during development relative to adults, and will likely not have a threshold [3].

A large number of chemicals have been identified as endocrine disruptors and humans can be exposed to them either due to their occupation and/or through dietary and environmental exposure [4]. Among the environmental pollutants, the best-characterized chemicals with endocrine disrupting properties considered to be involved in cancer etiology include dioxins, dioxin-like compounds, furans, polychlorinated biphenyls (PCBs), solvents, heavy metals, dichlorodiphenyltrichloroethane (DDT) and its metabolite dichorodiphenyldichloroethylene (DDE), 
and some other pesticides [5-6]. By far the most research into associations between EDs and tumors has been carried out with breast, prostate and testicular cancer [7-19], while thyroid cancer has received very little attention. Because of concerns associated with the increase of endocrine-related cancers, several International Scientific Organizations and/or International Scientific Advisory Committees have included among the priorities the need to implement epidemiological studies, to integrate epidemiological data with data on the environment, the food chain and human biomonitoring data, and to strengthen the studies of chemical mixtures exposure [20].

The aim of the present study was to investigate the incidence of breast, prostate, testicular and thyroid cancer in the Italian National Priority Contaminated Sites (NPCSs), served by cancer registries, included in the SENTIERI epidemiological surveillance programme [21]) where the presence of EDs reported to be linked to these tumors were reported. The Italian NPCSs are characterized by the presence of major industrial activities (e.g. refineries, petrochemical and metallurgic plants), and industrial and uncontrolled waste sites. In these NPCSs several environmental pollutants, are present, some of which with recognized or suspected endocrine disrupting properties.

Thyroid cancer was included even if the current understanding of its etiology does not clearly link it to an endocrine mechanism. Still some experimental and epidemiological studies have suggested that estrogen may play an important role in the development and progression of papillary thyroid cancer; this might make it plausible that xenoestrogens, such as cadmium or 2,3,7,8-tetrachlorodibenzo-p-dioxin (TCDD), might also contribute to the risk [22-23].

\section{Materials and Methods}

This is an exploratory ecological study. Cancer incidence (all ages) was investigated for breast (females), prostate, testis and thyroid, based on figures produced by the Italian Association of Cancer Registries (AIRTum), within SENTIERI Project - the Italian epidemiological surveillance system for population resident in NPCs, as discussed elsewhere [24]. Evidence of carcinogenicity of EDs for the tumours at study was assessed based on evaluation by International Scientific Organizations and International Scientific Advisory Committees; we took into consideration only the EDs that could be identified as environmental pollutants in the study areas. Relevant papers were identified from five major sources: International Agency for Research on Cancer (2015), Word Health Organization/United Nation Environment Programme (2013), Europen Commission (2012), European Environment Agency (2012), The Endocrine Society (2015) [1, 25-28]. This was considered an accurate account of the state of science on the potential human carcinogenic health effects of environmental exposure to EDs up to a year prior to their publication. In order to update such evidence, relevant literature published in the last four years has also been reviewed. This literature search was carried out in PubMed. Moreover, a search was carried out on available environmental data to ascertain the presence of EDs in the NPCSs at study. The environmental data were collected through the sources of the Italian Ministry of Environment, the legislative national decrees where the NCS are defined, the local environmental agencies [29-30]. The available data are related to the presence of the substances in the various environmental matrices, not necessarily to their concentrations. The existence of human biomonitoring data (blood, serum and milk) reporting high level of substances with endocrine disrupting properties and other monitoring data (food, plants) regarding the NPCSs at study was verified by a search in PubMed [31-44].

Age, gender, socio-economic-deprivation-index adjusted Standardized Incidence Ratios (SIRs), with their $90 \%$ confidence interval, were computed for each CS and cancer site by the Italian Association of Cancer Registries [24], with reference to the time window 1996-2005. Reference rates were derived from the pool of the cancer registries from Northern-Central Italy or from Southern-Central Italy, depending on the study area localization. 


\section{Results}

The NPCSs served by a Cancer Registry were seventeen. Three NPCSs were excluded from the study as the presence of EDs could be reasonably excluded. Therefore, the NPCSs finally included in the study were fourteen.

The environmental pollutants with suspected or recognized endocrine disrupting properties reported to be carcinogenic for the tumors at study by the five international scientific institutions/committees listed above are shown in table 1. Information on the characterization of the NPCSs with respect to the presence of major sources of pollution is reported in table 2, together with the indication of the EDs of interest detected in the environmental matrices, human biomonitoring data, and food monitoring data. The age, gender, socio-economic-deprivation-index adjusted SIRs, with their $90 \%$ confidence intervals (90\%CI), are reported in table 3. Excess incidence of one or more cancer site at study was found in twelve out of fourteen NPCSs. Significantly increased SIRs were found for breast cancer in eight CSs, for prostate cancer in six, for thyroid cancer (both gender) in four and for testicular cancer in two. Furthermore, not significantly increased SIRs were found in five CSs for testicular cancer and in two for thyroid cancer (males).

Table 1. Environmental pollutants with endocrine disrupting properties considered to be carcinogenic for the tumors at study by scientific institutions/advisory committees

\begin{tabular}{|c|c|c|c|c|c|}
\hline Cancer site & IARC [1] & WHO/UNEP [25] & $\begin{array}{c}\text { European } \\
\text { Commission [26] }\end{array}$ & $\begin{array}{c}\text { European } \\
\text { Environmental } \\
\text { Agency [27] }\end{array}$ & $\begin{array}{c}\text { The Endocrine } \\
\text { Society [28] }\end{array}$ \\
\hline Breast & $\begin{array}{l}\text { PCB } \\
\text { Ethylene oxide }\end{array}$ & $\begin{array}{l}\text { Dioxins } \\
\text { Furans } \\
\text { PCBs } \\
\text { Solvents }\end{array}$ & $\begin{array}{l}\text { Cadmium } \\
\text { Solvents }\end{array}$ & Oestrogenic EDs & Dioxins \\
\hline Prostate & $\begin{array}{l}\text { Arsenic } \\
\text { Cadmium } \\
\text { Rubber production } \\
\text { industry }\end{array}$ & $\begin{array}{l}\text { Arsenic } \\
\text { Cadmium } \\
\text { PCBs } \\
\text { Pesticides }\end{array}$ & $\begin{array}{l}\text { Arsenic } \\
\text { Cadmium } \\
\text { PCBs } \\
\text { Pesticides }\end{array}$ & Pesticides & $\begin{array}{l}\text { Cadmium } \\
\text { Farming } \\
\text { PCBs }\end{array}$ \\
\hline Testis & & $\begin{array}{l}\text { Prenatal exposure } \\
\text { to POPs } \\
\text { Fungicides } \\
\text { PBDE } \\
\text { Pesticides }\end{array}$ & $\begin{array}{l}\text { Organochlorine } \\
\text { chemicals (including } \\
\text { DDT and some } \\
\text { pesticides) } \\
\text { PCBs }\end{array}$ & $\begin{array}{l}\text { DDE } \\
\text { DDT } \\
\text { PCBs }\end{array}$ & $\begin{array}{l}\text { Arsenic } \\
\text { Cadmium } \\
\text { PCBs }\end{array}$ \\
\hline Thyroid & & $\begin{array}{l}\text { Pesticides } \\
\text { TCDD }\end{array}$ & $\begin{array}{l}\text { PCBs } \\
\text { Pesticides } \\
\text { Solvents }\end{array}$ & PCBs & \\
\hline
\end{tabular}

Abbreviations: DDE $=$ Dichorodiphenyldichloroethylene; DDT $=$ Dichlorodiphenyltrichloroethane; PBDE= Polybrominated Diphenyl Ethers; IARC= International Agency for the Research on Cancer; PCBs=Polychlorinated Biphenyls; POPs=Persistent organic pollutants; $\mathrm{TCDD}=2,3,7,8$-Tetrachlorodibenzo-p-dioxin; $\mathrm{WHO} / \mathrm{UNEP}=$ World Health Organization/United Nations Environment Programme 
Table 2. National Priority Contaminated sites (NPCSs) information on pollution sources, and endocrine disruptors (EDs) of interest detected in environmental matrices, human biological samples, and food

\begin{tabular}{|c|c|c|c|c|}
\hline \multirow{2}{*}{$\begin{array}{c}\text { National Priority } \\
\text { Contaminated Site (NPCS) }\end{array}$} & \multicolumn{2}{|c|}{ Area description } & \multicolumn{2}{|c|}{ Other data on EDs of interest } \\
\hline & Pollution sources & $\begin{array}{l}\text { EDs of interest detected in } \\
\text { environmental matrices }\end{array}$ & Human biomonitoring & Food \\
\hline Bacino Chienti & Shoe factories & $\begin{array}{l}\text { PCDDs/PCDFs, benzene, } \\
\text { toluene, other solvents }\end{array}$ & & \\
\hline Brescia Caffaro & Chemical plants, landfill & $\begin{array}{l}\text { As, PCBs, PCDDs/PCDFs, } \\
\text { chlorobenzene }\end{array}$ & $\begin{array}{l}\text { PCDDs/PCDFs, PCB } \\
\text { (human serum) }\end{array}$ & $\begin{array}{l}\text { PCB (food of animal } \\
\text { and vegetal origin); } \\
\text { (cattle's meat, cow } \\
\text { milk, forage) }\end{array}$ \\
\hline Fidenza & $\begin{array}{l}\text { Chemical plants, urban } \\
\text { and hazardous waste } \\
\text { landfills }\end{array}$ & $\begin{array}{l}\text { As, PCBs, PCDDs, benzene, } \\
\text { other solvents }\end{array}$ & & \\
\hline Litorale Domizio Flegreo & $\begin{array}{l}\text { Urban waste landfill, illegal } \\
\text { dumping sites, illegal } \\
\text { burning of waste }\end{array}$ & $\begin{array}{l}\text { As, PCBs, PCDDs, benzene, } \\
\text { other solvents }\end{array}$ & $\begin{array}{l}\text { PCDDs/PCDFs (breast } \\
\text { milk) }\end{array}$ & $\begin{array}{l}\text { PCDDs/PCDFs, (cow } \\
\text { and buffalo's milk ) }\end{array}$ \\
\hline Laguna Grado Marano & $\begin{array}{l}\text { Cellulose production plant, } \\
\text { dockyard }\end{array}$ & $\begin{array}{l}\text { As, PCDDs, benzene, other } \\
\text { solvents }\end{array}$ & & \\
\hline Laghi Mantova & $\begin{array}{l}\text { Metallurgy plants, paper } \\
\text { plant, petrochemical plant, } \\
\text { harbor area, industrial } \\
\text { waste landfills, hazardous } \\
\text { waste incinerator }\end{array}$ & $\begin{array}{l}\text { AS, Cd, PCDDs, } \\
\text { ethylbenzene, other } \\
\text { solvents }\end{array}$ & & PCBs (fruit, vegetables) \\
\hline Milazzo & $\begin{array}{l}\text { Oil refinery, steel plant, } \\
\text { thermal power plant, } \\
\text { electrical equipment } \\
\text { factories, illegal dumping } \\
\text { site }\end{array}$ & $\begin{array}{l}\text { PCDDs, heavy metals. } \\
\text { Benzo(a)pyrene }\end{array}$ & Cd, As (serum) & \\
\hline Porto Torres & $\begin{array}{l}\text { Chemical plants, } \\
\text { petrochemical plant, } \\
\text { refinery, power plant, } \\
\text { harbor area, illegal } \\
\text { dumping site }\end{array}$ & $\begin{array}{l}\text { As, Cd, chlorobenzene, } \\
\text { other solvents }\end{array}$ & & $\begin{array}{l}\text { PCDDs (fish and other } \\
\text { seafood) }\end{array}$ \\
\hline Priolo & $\begin{array}{l}\text { Chemical plants, } \\
\text { petrochemical plant, } \\
\text { refinery, harbor area, } \\
\text { hazardous waste landfills }\end{array}$ & PCB, hexachlorobenzene & $\begin{array}{l}\text { Dioxins, PCB, HCB } \\
\text { (breast milk and } \\
\text { puerperal hair) }\end{array}$ & $\begin{array}{l}\text { Cd, Pb, Hg, PCDDs, } \\
\text { organochlorine } \\
\text { compounds (fish and } \\
\text { other seafood) }\end{array}$ \\
\hline Sassuolo-Scandiano & $\begin{array}{l}\text { Ceramic industries, } \\
\text { industrial waste landfills }\end{array}$ & Heavy metals & & \\
\hline Taranto & Oil refinery, steel plant, & As, Cd, PCDDs, PCBs, & As, $\mathrm{Cd}$ in serum and & PCDDs, PCB (sheep and \\
\hline
\end{tabular}




\begin{tabular}{|c|c|c|c|c|}
\hline & $\begin{array}{l}\text { harbor area, cement plant, } \\
\text { controlled and illegal waste } \\
\text { dumps }\end{array}$ & benzene, xylene & $\begin{array}{l}\text { urine; PCDDs, PCBs } \\
\text { (serum and milk) }\end{array}$ & $\begin{array}{l}\text { cow's milk, clams); } \\
\text { PCB, HCB, PAHs (clams) }\end{array}$ \\
\hline Terni-Papigno & $\begin{array}{l}\text { Steel plant, hazardous } \\
\text { waste landfills }\end{array}$ & $\mathrm{PCB}$ & & \\
\hline Trento Nord & Chemical plant & Solvents & & \\
\hline Venezia (P. Marghera) & $\begin{array}{l}\text { Chemical plants, } \\
\text { petrochemical plant, oil } \\
\text { refinery, harbor area, illegal } \\
\text { dumping sites }\end{array}$ & $\begin{array}{l}\text { As, Cd, PCBs, PCDDs, } \\
\text { solvents }\end{array}$ & & $\begin{array}{l}\text { As, Cd, PCDDs, PCDFs } \\
\text { (shellfish) }\end{array}$ \\
\hline
\end{tabular}

Abbreviations: As=Arsenic; $\quad \mathrm{Cd}=$ Cadmium; $\quad \mathrm{CSs}=$ Contaminated sites; $\quad \mathrm{BPA}=$ Bisphenol $\mathrm{A}$; EDs= endocrine disruptors $\mathrm{HCB}=$ Hexachlorobenzene; $\quad$ PAHs=Polycyclic Aromatic Hydrocarbons; PBDE= Polybrominated Diphenyl Ethers; $\quad$ PCBs=Polychlorinated Biphenyls; PCDDs=Polychlorinated dibenzo-p-dioxins; $\quad$ PCDFs=Polychlorinated dibenzofurans; $\quad$ POPs= Persistent organic pollutants; $\quad$ SIR=Standardized Incidence Ratio; $\mathrm{TCDD}=2,3,7,8$-Tetrachlorodibenzo-p-dioxin

Table 3. Standardized Incidence Ratios (SIRs) with 90\% Confidence intervals (CI), 1996-2005

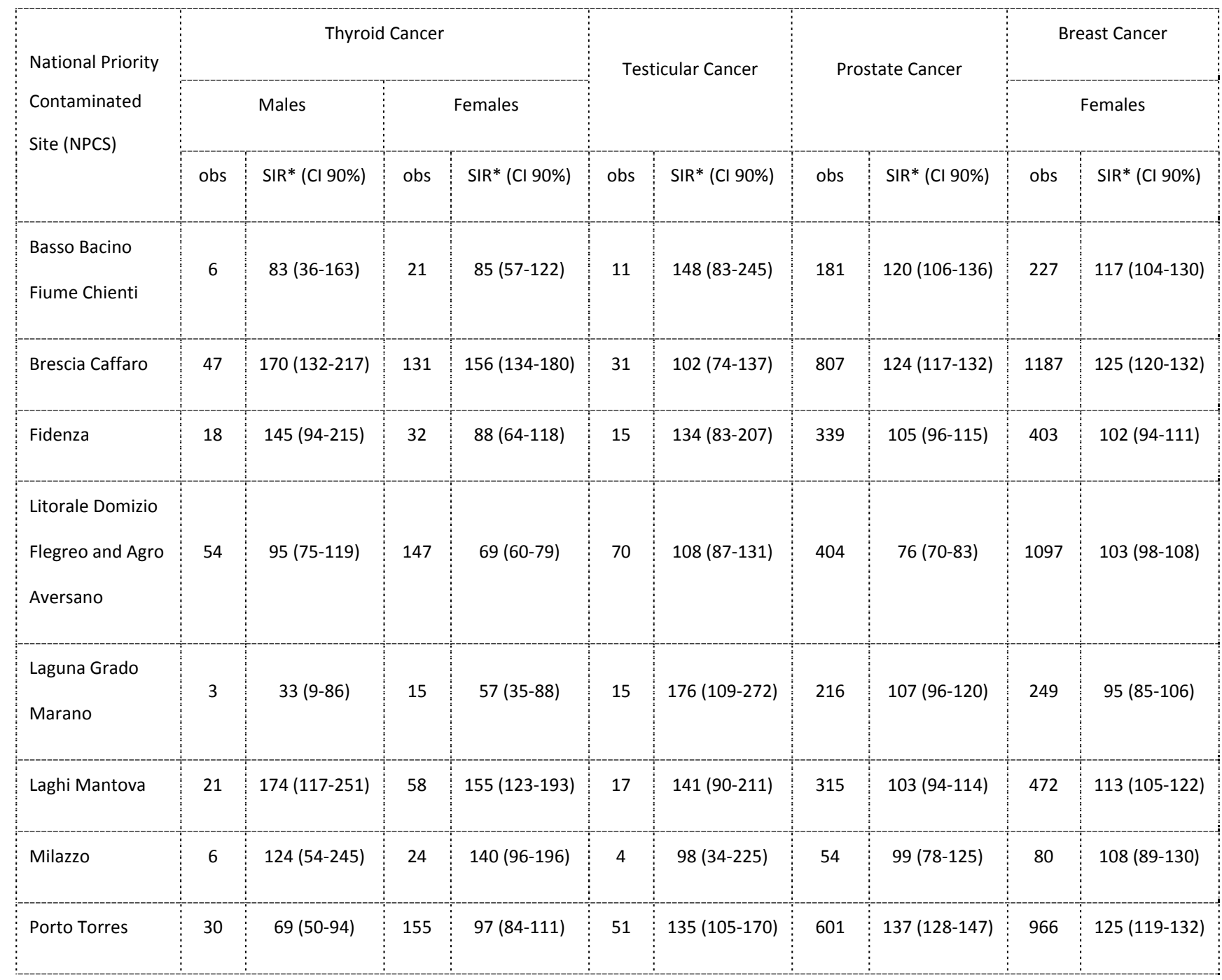


6 of 12

\begin{tabular}{|c|c|c|c|c|c|c|c|c|c|c|}
\hline Priolo & 34 & 89 (66-119) & 132 & 94 (81-109) & 37 & $103(77-136)$ & 417 & $105(96-114)$ & 712 & $111(104-118)$ \\
\hline Sassuolo & 41 & $146(111-190)$ & 106 & $130(110-152)$ & 39 & 121 (91-159) & 540 & 92 (86-99) & 702 & $90(85-96)$ \\
\hline Taranto & 34 & $158(116-210)$ & 98 & $120(101-142)$ & 20 & $108(72-158)$ & 303 & $130(118-143)$ & 497 & 145 (134-156) \\
\hline Terni Papigno & 32 & $106(77-142)$ & 67 & $66(53-81)$ & 32 & $121(88-163)$ & 577 & 89 (83-95) & 902 & $114(107-120)$ \\
\hline Trento Nord & 20 & $71(47-103)$ & 71 & $70(57-85)$ & 32 & $104(76-140)$ & 527 & $88(82-94)$ & 876 & $98(92-103)$ \\
\hline $\begin{array}{l}\text { Venezia Porto } \\
\text { Marghera }\end{array}$ & 57 & 74 (59-92) & 165 & $71(62-81)$ & 76 & 94 (77-114) & 2075 & $103(100-107)$ & 3045 & $110(107-114)$ \\
\hline
\end{tabular}

* adjusted for age and socio-economic deprivation index

Abrbreviation: obs $=$ observed cases

\section{Discussion}

An excess in incidence was mainly found in several NPCs for breast and prostate cancers, which are relatively common tumors. The rarity of testicular and thyroid cancers, and the small number of cases on which the findings were based, might explain the lower number of significant excesses Additional research should take into account the peculiarity of each of these tumors (different window of vulnerability, peak incidence, reported shift of the age of onset and/or increase of specific histotypes, as for thyroid cancer). Due to the rarity of testicular and thyroid cancer, an extension of the length of study window is indicated.

\section{Conclusions}

In conclusion, even if increased incidence of one or more cancer sites at study was found in several NPCSs, the ecological study design and the multifactorial etiology of the considered tumors do not allow reaching conclusions in terms of causal links with environmental contamination. However, the observed increase encourage to perform studies with an analytical epidemiological approach. Moreover, in light of the observation of some excesses in SIRs, endocrine disruptors reported to be carcinogenic should be considered as a priority in environmental clean-up, as recommended by several scientific institutions and/or advisory committees [2,20,45-46]. Meanwhile, in the contaminated sites, a continuing epidemiological surveillance is warranted, and an exposure assessment that include the detection of further contaminants with ED properties, also emerging (e.g. PFAS, steroidal estrogens), is recommended.

\section{References}

1. World Health Organization/United Nations Environment programme (WHO/UNEP). Bergman, A.; Jerrold, J.; Heindel, J.J; Jobling, S.; Karen, A.;Kidd K.A.; Zoeller R.T. State of the science of endocrine disrupting chemicals 2012. An assessment of the state of the science of endocrine disruptors prepared by a group of experts for the United Nations Environment 
Programme and World Health Organization. 2013. Available online: http://www.who.int/ceh/publications/endocrine/en// (accessed on 24 October 2016)

2. Solecki, R.; Kortenkamp, A.; Bergman, Å.; Chahoud, I.; Degen, G.H.;Dietrich, D.; Greim, H.; Håkansson, H.; et al. Scientific principles for the identification of endocrine-disrupting chemicals: consensus statement. Arch Toxicol. 2017, 91, 1001-1006.

3. Vandenberg, L.N.; Colborn, T.; Hayes, T.B.; Heindel, J.J.; Jacobs, Jr D.R.; Lee, D.H.; Shioda, T.; Soto, A.M.; vom Saal, F.S.; Welshons, W.V.; et al. Hormones and endocrine-disrupting chemicals: low-dose effects and nonmonotonic dose responses. Endocr Rev. 2012, 33, 378-455.

4. Kabir, E.R.; Rahman, M.S.; Rahman, I. A review on endocrine disruptors and their possible impacts on human health. Environ Toxicol Pharmacol. 2015, 40, 241-58.

5. Faniband. M.; Lindh, C.H.; Jönsson, B.A. Human biological monitoring of suspected endocrine-disrupting compounds. Asian J Androl. 2014, 16, 5-16.

6. Soto, A.M.; Sonnenschein, C. Nat. Rev. environmental causes of cancer: endocrine disruptors as carcinogens. Endocrinol. 2010, 6, 363-370.

7. Morgan, M.; Deoraj, A.; Felty, Q.; Roy, D. Environmental estrogen-like endocrine disrupting chemicals and breast cancer. Mol Cell Endocrinol. 2016 [in press]. Available online: http://dx.doi.org/10.1016/j.mce.2016.10.003 (accessed on 12 December 2016).

8. Liu, R.; Nelson, D.O.; Hurley, S.; Hertz, A.; Reynolds, P. Residential exposure to estrogen disrupting hazardous air pollutants and breast cancer risk: the California Teachers Study. Epidemiology. 2015, 26, 365-373.

9. Larsson, S.C.; Orsini, N.; Wolk, A. Urinary cadmium concentration and risk of breast cancer: a systematic review and dose-response meta-analysis. Am J Epidemiol. 2015, 182, 375-380.

10. Soto, A.M.; Sonnenschein, C. Endocrine disruptors: DDT, endocrine disruption and breast cancer. Nat Rev Endocrinol. 2015, 11, 507-8.

11. Aquino, N.B.; Sevigny, M.B.; Sabangan, J.; Louie, M.C. Role of cadmium and nickel in estrogen receptor signaling and breast cancer: metalloestrogens or not? J Environ Sci Health C Environ Carcinog Ecotoxicol Rev. 2012, 30, 189-224.

12. Sweeney, M.F.; Hasan, N.; Soto, A.M.; Sonnenschein C. Environmental endocrine disruptors: Effects on the human male reproductive system. Rev Endocr Metab Disord. 2015, $16,341-357$. 
13. Giannandrea, F.; Paoli, D.; Figà-Talamanca, I.; Lombardo, F.; Lenzi, A.; Gandini, L. Effect of endogenous and exogenous hormones on testicular cancer: the epidemiological evidence. Int J Dev Biol. 2013, 57, 255-263.

14. Paoli D.; Giannandrea, F.; Gallo, M.; Turci, R.; Cattaruzza, M.S.; Lombardo, F.; Lenzi A, Gandini L. Exposure to polychlorinated biphenyls and hexachlorobenzene, semen quality and testicular cancer risk. $J$ Endocrinol Invest. 2015, 38, 745-52.

15. Prins, G.S. Endocrine disruptors and prostate cancer risk. Endocr Relat Cancer. 2008, 15, 649-56.

16. McGlynn, K. A.; Trabert, B. Adolescent and adult risk factors for testicular cancer.; Nat Rev Urol. 2012, 9, 339-349.

17. Silva, J.F.; Mattos I.E.; Luz, L.L.; Carmo, C.N.; Aydos, R.D. Exposure to pesticides and prostate cancer: systematic review of the literature. Rev Environ Health. 2016, 31, 311-327.

18. Emeville, E.; Giusti, A.; Coumoul, X.; Thomé, J.P.; Blanchet, P.; Multigner, L. Associations of plasma concentrations of dichlorodiphenyldichloroethylene and polychlorinated biphenyls with prostate cancer: a case-control study in Guadeloupe (French West Indies). Environ Health Perspect. 2015, 123, 317-323.

19. Béranger, R.; Le Cornet, C.; Schüz J, Fervers B. Occupational and environmental exposures associated with testicular germ cell tumours: systematic review of prenatal and life-long exposures. PLoS One. 2013, October 14. Available online: http://dx.doi.org/10.1371/journal.pone.0077130 (accessed on 28 November 2016)

20. The 2013 Berlaymont Declaration on Endocrine Disrupters. Available online: http://www.brunel.ac.uk/_data/assets/pdf_file/0005/300200/The_Berlaymont_Declaration on_Endocrine_Disrupters.pdf(accessed on 25 September 2016).

21. Pirastu, R.; Comba, P.; Conti, S.; Iavarone, I.; Fazzo, L.; Pasetto, R.; Zona, A.; Crocetti, E.; Ricci, P. [SENTIERI project - Epidemiological study of residents in national priority contaminated sites]. Epidemiol Prev. 2014, 38, 1-169.

22. Zhu, P.; Liao, L.Y.; Zhao, T.T.; Mo, X.M.; Chen, G.G.; Liu, Z.M. GPER/ERK\&AKT/NF-кB pathway is involved in cadmium-induced proliferation, invasion and migration of GPER-positive thyroid cancer cells. Mol Cell Endocrinol. 2016, 442, 68-80.

23. Huang, Y.; Dong, W.; Li J.; Zhang H.; Shan Z.; Teng W. Differential expression patterns and clinical significance of estrogen receptor- $\alpha$ and $\beta$ in papillary thyroid carcinoma. $B M C$ Cancer. 2014, 14, 383. 
24. Crocetti, E.; Pirastu, R.; Buzzoni, C.; Minelli, G.; Manno, V.; Bruno, C.; Fazzo, L.; et al. SENTIERI Project: results]. Epidemiol Prev. 2014, 38, 29-124.

25. International Agency for Research on Cancer (IARC). List of Classifications by cancer sites with sufficient or limited evidence in humans, Volumes 1 to 112. Last update, 23 March 2015. Available online: https://monographs.iarc.fr/ENG/Classification/Table4.pdf (Accessed on 21 June 2016).

26. European Commission. Kortenkamp, A. ; Evans, R.; Martin, O.; McKinlay, R.; Orton, F.; Rosivatz, E. State of the art assessment of endocrine disruptors. Final report. Annex 1. Revised version, 29 January 2012. Available online: http://ec.europa.eu/environment/chemicals/endocrine/pdf/annex1_summary state of sciece .pdf (Accessed on 21 June 2016)

27. European Environment Agency. The impact of endocrine disrupters on wildlife, people and their environments-the Weybrige+15(1996-2011) Technical report N. 2/2012. Available online: $\quad$ http://www.eea.europa.eu/publications/the-impacts-of-endocrine-disrupters (Accessed on 21 June 2016)

28. Gore, A.C.; Chappell, V.A.; Fenton, S.E.: Flaws, J.A.; Nadal, A.; Prins, G.S.; Toppari J.; Zoeller R.T. EDC-2: The Endocrine Society's second scientific statement on Endocrine-disrupting chemicals. Endocr Rev. 2015,36,E1-E150.

29. Musmeci, L.; Bellino, M.; Falleni, F.; Piccardi, A.[Environmental characterization of the National Contaminated Sites in SENTIERI project]. Epidemiol Prev. 2011, 35, 20-3.

30. Beccaloni, E.; Cicero, M.R.; Falleni, F.; Piccardi, A.; Scaini, F.; Soggiu, M.E.; Vanni, F.; Carere, M. [Environmental characterization and exposure evaluation]. Epidemiol Prev. 2014, $38,137-143$.

31. Miniero, R.; Ingelido, A.M.; Abballe, A.; di Domenico, A.; Valentinia, S.; Marra, V. ; Barbieri, P.G.; Garattini, S.; Speziani, F.; De Felip E. Occupational exposure to PCDDs, PCDFs, and DL-PCBs in metallurgical plants of the Brescia (Lombardy Region, northern Italy) area. Chemosphere. 2017, 166, 418-421.

32. Vimercati, L.; Baldassarre, A.; Gatti, M.F.; Gagliardi, T.; Serinelli, M.; De Maria, L.; Caputi, A.; Dirodi, A.A.; et al. Non-occupational exposure to heavy metals of the residents of an industrial area and biomonitoring. Environ Monit Assess. 2016,188, 673.

33. Ingelido, A.M.; Abate, V.; Abballe, A.;, Albano, F.L.; Battista, T.;., Carraro, V.; Conversano, M.; Corvetti, R.; et al. Concentrations of polychlorinated dibenzodioxins, polychlorodibenzofurans, and polychlorobiphenyls in women of reproductive age in Italy: A 
human biomonitoring study. Int J Hyg Environ Health. 2016 [in press]. Available online: http://dx.doi.org/10.1016/j.ijheh.2016.11.009 (Accessed on 5 December 2016).

34. Interdonato, M.; Bitto, A.; Pizzino, G.; Irrera, N.; Pallio, G.; Mecchio, A.; Cuspilici, A.; Minutoli, L.; Altavilla, D.; Squadrito, F. Levels of heavy metals in adolescents living in the industrialised area of Milazzo-Valle del Mela (northern Sicily). $J$ Environ Public Health. 2014, Volume 2014, Article ID 326845. Available on line: http://dx.doi.org/10.1155/2014/326845 (Accessed on 19 April 2016).

35. Bianco, G,; Zianni, R.; Anzillotta, G.; Palma, A.; Vitacco, V.; Scrano, L.; Cataldi, T.R. Dibenzo-p-dioxins and dibenzofurans in human breast milk collected in the area of Taranto (Southern Italy): first case study. Anal Bioanal Chem. 2013, 405, 2405-2410.

36. Vimercati, L.; Cuccaro, F.; Serinelli, M.; Bisceglia, L.; Galise, I.; Conversano, M.; Minerba, S.; Mincuzzi, A.; et al. Exposure assessment to heavy metals in general population in a polluted area through biological monitoring. Proceedings of the 16th International Conference on Heavy Metals in the Environment. Volume 1, 2013.

37. Iavarone, I.; De Felip, E.; Ingelido A.M.; Iacovella, N.; Abballe, A.; Valentini, S.; Marra, V.; Violante, N.; et al. [Exploratory biomonitoring study among workers of livestock farms of the Taranto Province]. Epidemiol Prev. 2012, 36, 321-331.

38. Esposito, M.; Serpe F.P.; Neugebauer, F.; Cavallo, S.; Gallo, P.; Germana Colarusso, G.; Baldi, L; Iovane, G; Serpe, L. Contamination levels and congener distribution of PCDDs, PCDFs and dioxin-like PCBs in buffalo's milk from Caserta province (Italy). Chemosphere. 2010, 79, 341-348.

39. Turrio-Baldassarri, L.; Abate, V.; Battistelli, C.L.; Carasi, C.; Casella, M.; Iacovella, N.; Indelicato, A.; et al. PCDD/F and PCB in human serum of differently exposed population groups of an Italian city. Chemosphere. 2008, 73, S228-S234.

40. Giandomenico, S.; Spada, L.; Annicchiarico, C.; Assennato, G.; Cardellicchio, N.; Ungaro, N.; Di Leo, A. Chlorinated compounds and polybrominated diphenyl ethers (PBDEs) in mussels (Mytilus galloprovincialis) collected from Apulia Region coasts. Mar Pollut Bull. 2013,73, 243-251.

41. Matozzo, V.; Binelli, A; Parolini, M; Locatello, L.; Marina M.G.. Biomarker responses and contamination levels in the clam Ruditapes philippinarum for biomonitoring the Lagoon of Venice (Italy). J Environ Monit. 2010, 12, 776-786

42. Grassi, P.; Fattore E.; Generoso, C.; Fanelli, R.; Arvati, M.; Zuccato, E. Polychlorobiphenyls (PCBs), polychlorinated dibenzo-p-dioxins (PCDDs) and dibenzofurans (PCDFs) in fruit and vegetables from an industrial area in northern Italy. Chemosphere. 2010, 79, 292-298. 
43. Turrio-Baldassarri, L.; Alivernini, S.; , Carasi, S.; Casella, M.; Fuselli, S.; Iacovella, N.; Iamiceli, A.L.; La Rocca, C.; Scarcella, C.; Battistelli, C.L. PCB, PCDD and PCDF contamination of food of animal origin as the effect of soil pollution and the cause of human exposure in Brescia. Chemosphere. 2009, 76, 278-85.

44. Cardellicchio, N.; Buccolieri, A.; Giandomenico, S.; Lopez, L.; Pizzulli, F.; Spada, L. Organic pollutants (PAHs, PCBs) in sediments from the Mar Piccolo in Taranto (Ionian Sea, Southern Italy). Mar Pollut Bull. 2007, 55, 451-458.

45. American Public Health Association. A Precautionary Approach to Reducing American Exposure to Endocrine Disrupting Chemicals. Available online: http://www.apha.org/policies-and-advocacy/public-health-policy-statements/policy-databas e/2014/07/09/09/03/a-precautionary-approach-to-reducing-american-exposure-to-endocrine -disrupting-chemicals/ (accessed on 28 November 2016)

46. European Environment Agency. Late lessons from early warnings: science, precaution, innovation. EEA Report No 1/2013. Available online:http://www.eea.europa.eu/publications/late-lessons-2 (accessed on 28 November 2016)

\section{The following abbreviations are used in this manuscript:}

$\begin{array}{ll}\text { AS } & \text { Arsenic } \\ \text { Cd } & \text { Cadmium } \\ \text { CI } & \text { Confidence Interval } \\ \text { CSs } & \text { Contaminated Sites } \\ \text { DDE } & \text { Dichorodiphenyldichloroethylene } \\ \text { DDT } & \text { Dichlorodiphenyltrichloroethane } \\ \text { EDs } & \text { Endocrine disruptors } \\ \text { IARC } & \text { International Agency for Research on cancer } \\ \text { HCB } & \text { Hexachlorobenzene } \\ \text { NPCSs } & \text { National Priority Contaminated Sites } \\ \text { PAHs } & \text { Polycyclic Aromatic Hydrocarbons } \\ \text { PBDE } & \text { Polybrominated Diphenyl Ethers } \\ \text { PCBs } & \text { Polychlorinated Biphenyls } \\ \text { PCDDs } & \text { Polychlorinated Dibenzo-p-dioxins } \\ \text { PCDFs } & \text { Polychlorinated Dibenzofurans } \\ \text { POPs } & \text { Persistent Organic Pollutants } \\ \text { SIR } & \text { Standardized Incidence Ratio } \\ \text { TCDD } & \text { 2,3,7,8-Tetrachlorodibenzo-p-dioxin } \\ \text { UNEP } & \text { United Nations Environment Programme } \\ \text { WHO } & \text { World Health Organization }\end{array}$




\section{Authors' contribution}

MB conceived the whole study, and drafted the manuscript. AZ contributed to reviewing the study design and the manuscript. EB contributed to collecting environmental data. MC contribute to collecting environmental data and commenting the manuscript. PC helped in designing the study and edited the manuscript in the final form. All authors read and approved the version submitted.

\section{Declaration of interest}

The authors declare that there is no conflict of interest that could be perceived as prejudicing the impartiality of the research reported

\section{Funding}

This research did not receive any specific grant from any funding agency in the public, commercial or not-for-profit sector.

(C) 2017 by the authors. Licensee Preprints, Basel, Switzerland. This article is an open access article distributed under the terms and conditions of the Creative Commons by Attribution (CC-BY) license (http://creativecommons.org/licenses/by/4.0/). 